doi:10.7592/TF10.esoteerika

\title{
Rollid ja rollikäitumine interneti esoteerikafoorumites ${ }^{1}$
}

\section{Reet Hiiemäe}

\begin{abstract}
Teesid: Artiklis vaadeldakse interneti avatud esoteerikafoorumite vestluste põhjal, kuidas loovad foorumikasutajad kasutajanimede ja profiilipiltide valiku kaudu oma virtuaalidentiteeti ning mil määral kasutatakse sealjuures motiive vanemast usundist ja mütoloogiast. Samuti jälgitakse foorumivestlustes avalduvat rollikäitumist ja püütakse välja tuua selle seaduspärasusi, funktsioone ning eesmärke. Näiteks on tähelepanuväärsed "oma" ja "võõra" opositsiooni avaldumine, vaenlase kuvandi loomine ning virtuaalhierarhiate kujunemine nii foorumisiseselt kui ka teiste foorumitega suhestudes, samuti rollikonfliktid.
\end{abstract}

Märksõnad: esoteerikafoorumid, identiteet, internet, rollid, tänapäeva usund

Interneti esoteerikafoorumite all mõistan interneti avatud vestlusfoorumeid, milles toimuvad arutelud paranähtuste jm kaasaegse new age stiilis usundifenomenide (nt kohtumised tulnukate ja teispoolsuse olenditega, selgeltnägemine, maagia, meeleülesed võimed) üle. Eelkõige vaatlen foorumiarutelusid, mille tüüpiline struktuur on järgmine: abivajaja esitab mingi spetsiifilise küsimuse, näiteks kuidas vabaneda needusest, painajast, energiavampiirist, rahamurest, kuidas seletada öist häältekuulmist või unenägu jne, millele foorumiliikmed vastavad. Artikli koostamisel olen kasutanud järgmistel veebilehtedel leiduvaid eestikeelseid foorumeid: http:// para-web.org, http://tuulepesa.zzz.ee, http://pesa.ingliabi.ee (varasema aadressiga: http://www.puhastus.planet.ee/forum), http:// vaimumaailm.ee ja http://foorum.luuleviilma.ee.

${ }^{1}$ Artikkel on valminud sihtfinantseeritava teema SF 0030181508 toetusel. 
Teatud mööndustega olen vaadelnud ka veebilehel http:// skeptik.ee leiduvat foorumit, mida ei saa nimetada otseselt esoteerikafoorumiks, kuna selles on põhirõhk teiste inimeste usundilistes väidetes ja tõekspidamistes kahtlemisel, kuid see ei takista foorumis osalejaid puhuti ise väljendamast kindlaid uskumuslikke seisukohti. Laiema pildi saamiseks ja paralleelide leidmiseks olen tutvunud paari meile kultuuriliselt lähedase maa võrreldava allikaga (http://www.esoterikforum.at ja http:// www.esoterikforum.de kui Austria ja Saksamaa suuremad ja tuntumad esoteerikale keskendunud portaalid), samuti mõningate üldfoorumite esoteerikat käsitlevate rubriikidega.

Käsitluse huvikeskmes on asünkroonsete foorumite kasutajaidentiteedi ja -rollide loomisel avalduvad seaduspärasused ja valikud ning nende kasutamise põhjused.

\section{Foorumisuhtluse spetsiifikast}

Kui laiema internetikasutuse algusaastatel uuriti pigem viise, kuidas kanduvad tavasuhtluse kommunikatsioonimustrid üle internetisuhtlusse (nt Bargh, McKenna 2003), siis nüüdseks on põhjust uurida aina enam ka seda, kuidas mõjutavad internetis võetavad rollid ja identiteedid omakorda inimeste läbikäimist ja käitumist reaalelus (nt Kunz 2012). Näiteks märgib Ameerika meediauurija Patricia Wallace tabavalt, et üha sagedamini mängib esmakohtumisel ja esmamulje loomisel rolli võrgupersoon, sest üha enam toetutakse esimeste kontaktide puhul elektronkirjadele ja vestlusfoorumitele (vrd Wallace 2002, 27). Siin on käesoleva artikli materjalist lähtuvalt asjakohane täpsustus, et osa esoteerikafoorumite kasutajatest kohtub aja jooksul tõesti ka reaalelus (näiteks mõnel temaatilisel üritusel) ning sellistel juhtudel mängib varasem virtuaaltutvuse kaudu loodud mulje kahtlemata oma rolli (seda on kinnitanud ka foorumikasutajad ise, märkides näiteks, et ootasid foorumis väga jutukatelt ja väljakutsuvatelt sõnavõtjatelt sama tegelikul kohtumisel, kuid kogesid vastupidist; vrd kokkutulekuarutelu foorumis para-web.org, apr 2011). Valdav osa foorumikasutajaist aga ei kohtu tõenäoliselt näost näkku kunagi ja seega piirdubki nende puhul lävimine võrguidentiteedi pakutavate võimalustega.

Esoteerikafoorumite (nagu ka muude internetifoorumite) kommunikatiivseks esmatasandiks on nendes toimuvad arutelud. Foo- 
rumites avalduv rollikäitumine on vaadeldav pigem metakommunikatsioonina - see on aruteludes sisalduvate otseselt mittesõnastatud ja osalt ka mitteteadvustatud hoiakute ning foorumisiseselt võetud rollide peegeldus. Seega on siin vaid osaliselt jälgitav selline teadlik rollivõtt ja -käitumine nagu näiteks fantaasia- ja rollimängijate kogukondades.

Rolli- ja identiteediloome elementide hulk foorumisuhtluses on piiratud, mis võib suhtlemisel olla ühtaegu nii plussiks kui ka miinuseks. Kui traditsioonilisel näost näkku suhtlemisel moodustavad visuaalne, auditiivne ja verbaalne pool ühtse terviku, mille põhjal kokkupandud koondmuljet on raske muuta, siis internetis lasub väljendusvahendite osas põhirõhk tekstil, piiratud visuaalse komponendi (nt profiilipildi) saab inimene lisada või seda vahetada igal ajal vastavalt oma suvale. Seega toimub internetifoorumites rollide loomine ja vahetamine palju hõlpsamini kui päriselus, kuna seal ei sea isikule piiranguid tema tegelik välimus, positsioon ega isegi sugu. Samuti on internetis tunduvalt kitsendatud paraverbaalsete ja nonverbaalsete suhtlusvahendite kasutamine (vrd Roth 2009, 109). Tulemuseks on selliste muljeelementide nagu nimi, profiilipilt ja tekstiloomeoskus ebaproportsionaalselt suur kandvus. Sama märgib Wallace $(2002,47)$ : “Tekstipõhises keskkonnas ei saa te oma kõrget staatust esile tuua nii nagu visuaalses režiimis - näiteks kuldkäekella abil. [---] Mainekujunduse ainsaks vahendiks on arvutiklaviatuur." Kuid nagu öeldud, pakub virtuaalne maailm staatuse väljendamiseks ja muuks enesepresentatsiooniks kokkuvõttes tunduvalt fantaasiarohkemaid võimalusi, kui seda oleks näiteks virtuaalse kuldkellaga uhkeldamine.

Samas raskendab foorumisuhtluses orienteerumist sensoorse info üleküllus - kui tavavestluses on inimese vestluspartnerite arv piiratud paari kuni maksimaalselt paarikümnega, siis foorumites on potentsiaalseid sõnavõtjaid tihtilugu tuhandeid (oktoobris 2012 oli käsitletud esoteerikafoorumitest näiteks para-web.org registreerunud kasutajaid 400, foorumil tuulepesa.zzz.ee üle 2300 , foorumil esoterik.de koguni üle 5500). Seetõttu kaldutakse internetisuhtluses lähtuma ökonoomsusprintsiibist ehk siis tuginema hinnangute andmisel piiratud hulgale märkidele, mis võivad tegeliku isiku omadustest moodustada vaid marginaalse osa (või luua pildi omadustest, mida tegelikul isikul ei olegi). Kognitiivse ülekoormatuse vähendamiseks hakkab nende märkide põhjal toimuma inimeste (vähemalt esmane) jagamine stereotüüpsetesse kategooriatesse, 
kusjuures suhtumine mingisse kategooriasse sõltub konkreetsest foorumist. Nii näiteks tehakse interneti perefoorumites veidra ja vigase keelekasutuse ning ebatsensuursete väljendite põhjal järeldusi inimese vaimse võimekuse kohta ja juhitakse kirjavigadele korrigeerivalt tähelepanu (vrd Reinaus 2008, 165), ent esoteerikafoorumites omapärast keelekasutust üldjuhul ei taunita. Ka kasutajanime märgiline tähendus võib olla foorumiti erinev. Näiteks kui kasutaja nimega Mefistofeles võtaks sõna mõnes pereportaalis lapse isana või mõne päevalehe usuteemalise artikli kommentaatorina, võiks ta oma nime tõttu mõjuda mittetõsiseltvõetavana, kuid esoteerikafoorumis (antud juhul para-web.org) lisab selline nimi pigem respekti või tundub lihtsalt normaalsena. Samas nähtub esoteerikafoorumite postitustest, et siin sõltub postitajatesse suhtumine eelkõige postituste sisust ja laadist, mitte kasutajanimest. Seega võivad näiteks nii kasutajate Legallyblond kui Mefistofeles postitused olla samavõrra aktsepteeritud. Alles siis, kui mõni kasutaja muutub provotseerivaks, võidakse vasturünnakus hakata kasutama relvana tema vastu ka tema nime ja selle konnotatsioone.

Sotsiaalsele kommunikatsioonile internetifoorumis on omane jadavorm: "Foorumitekstid ei ole peaaegu kunagi üksiktekstid, vaid osad seeriast. Iga järgmine tekst samalt (või ka teiselt) kasutajalt võib eelmise tühistada" (vrd Roth 2009, 103). Ka ajaliselt puudub piirang, millal mingile teemaalgatusele vastamine lõpetatakse vahel võib esmapostituse ja viimase vastuse vahel olla vahet rohkem kui terve aasta. Mõned foorumid on siiski hakanud selles osas rakendama teatud kitsendusi, näiteks võivad moderaatorid teema lõpetada, kui argumendid ja vastuväited hakkavad korduma ja sisulist edasiliikumist enam ei toimu.

Internetifoorum on ühtaegu nii otsesuhtlus kui ka massikommunikatsioon (vrd Roth 2009, 105). Lisaks otsestele sõnavõtjatele on igal postitusel määramatu hulk passiivseid lugejaid. Erinevalt otsekommunikatsioonist ei eeldata, et küsimustele vastamine toimub sünkroonselt, seega on teadete formuleerimiseks rohkem aega ja vastaja(te)le ei räägi keegi vahele - inimene saab läbimõeldult oma lugu ja identiteeti kujundada. Mõne internetiuurija arvates avaneb inimesel võimalus luua foorumis just tegelikust positiivsem kuvand, nt Joinson 2005, 24: "Sõnumisaatja saab oma enesepresentatsiooni optimeerida - ta saab esitleda end positiivsemas valguses kui näost näkku suhtlemisel, kuna ta ei pea muretsema oma mitteverbaalse käitumise pärast." 


\section{Rolliloome elemendid}

Foorumite rolliloome elemendid jagunevad otseselt foorumi moderaatorite-liidrite poolt etteantud elementideks ning kasutajate endi vabalt genereeritavateks elementideks.

\section{Foorumi moderaatorite-liidrite poolt etteantud elemendid}

Nagu paljudes teisteski internetifoorumites märgitakse ka mitmetes esoteerikafoorumites kasutajate erinevad staatused ära tärnide ja tiitlitega, näiteks foorumis pesa.ingliabi.ee on kasutusel järgmine hierarhia: külaline 0 tärni, uustulnuk 1 tärn, noorliige 2 tärni, täisliige 3 tärni, suurliige 4 tärni, foorumi kangelane 6 tärni, superliige (enamasti moderaator) 7 tärni.

Foorumis para-web.org kohtab muuhulgas selliseid tiitleid nagu supermoderator, vana kala, tegevveteran.

Vaimumaailm.ee on kõige selgemalt ühe liidri juhtimisel loodud virtuaalimpeerium, mille liider Tokroda on ka avalikkuses endale nime teinud nn nõia, maagi ja teadmamehena. Tokroda tutvustab foorumis enda ülesehitatud mittekristlikku usundilist hierarhiat, millesse kaasatakse sujuvalt ka foorumiliikmete hierarhia - iseennast nimetab liiderliige Valgusjumalaks, teistele liikmetele jagatakse tiitleid: pooljumal, ingel, haldjas, inimene. Samas võib liiderliige neid tiitleid oma suva järgi muuta.

Foorumi kangelased jm superliikmed on üldiselt ka kõige aktiivsemad foorumikülastajad, kellest paljud veedavad suurema osa ajast foorumisse sisselogitult, omades seega ka kõige paremat ülevaadet foorumis toimuvast ja esinedes valdavalt vastaja rollis. Küsija/abivajaja rollis on kõige sagedamini tärnisüsteemis madalal positsioonil olev uusliige või foorumi külaline. Seega paneb tärnisüsteem ühtlasi paika foorumisisesed üldised kompetentsusraamid.

\section{Kasutajate genereeritavad elemendid}

Kasutajanimed ja profiilipildid (nn avatarid). Foorumite kasutajanimed ja profiilipildid on oluline osa foorumisisesest identiteediloomest - kuna kasutajanimi ja -pilt ilmuvad inimese iga postituse juurde, on neil märkimisväärne kaal tervikmulje loomisel. Reeli Reinaus on http://www.perekool.ee kasutajanimesid uurides samuti 
märganud, et kindla kasutajanimega foorumisse tulles etendatakse teatud rolli, mille kaudu teised isikut identifitseerivad (Reinaus 2008, 163). Mitmed foorumiliikmed kasutavad võimalust lisada oma postituste alla lühike korduv tunnustekst, mis annab aimu inimese usundilistest vaadetest või üldisemalt eluhoiakutest, näiteks: "Tegelikult on kõik lihtne aga me pole sellest veel aru saanud" (para-web. org) või "Ma olen oma jumalat näinud!" (tuulepesa.zzz.ee).

Inimene paneb oma profiilipildiks harva enda foto, enamasti valitakse selle asemele mingi tähenduslik sümbol, märk või pilt esoteerikafoorumites on populaarsed inglipildid (kõige ülekaalukam rühm), pühakud-buddhad, päikeseloojangud ning muud tuld ja valgust sümboliseerivad kujutised. Samas võib valitud visuaalne kujund moonutada tõde nt inimese vanuse ja soo kohta (vrd Wallace 2002, 41). Kui näiteks kasutaja profiilipildiks on valitud Disney multifilmi stiilis haldjatüdruk, on tõenäoline, et foorumiliikmed, kes teda lähemalt ei tunne, peavad teda nooreks neiuks, samuti võidakse juba ette anda hinnang, et antud kasutaja on kogenematu ja naiivne. Samas kinnitasid foorumikasutajad, kellega vestlesin, et profiilipilt loob siiski vaid esmase mulje; kui kasutaja jutt on järjepidevalt arukas, ei mängi enam rolli, kas tema profiilipilt on tobe või mitte.

Vastastikuse mõistetavuse säilitamiseks ja kommunikatiivsete eesmärkide täitmiseks peab nime- ja sümbolivalik toimuma teatud määral etteantud märgisüsteemi raames, et vähemalt asjassepühendatud teaksid, mis tähendust need kannavad. Foorumiliikmed taotlevad oma kasutajaidentiteedi loomisel üldiselt efektsust ja unikaalsust, aga süsteemil on nivelleeriv mõju, ja selle tulemusena on kasutusel üsna ühetaolised vägevuse ja tarkuse või teispoolsusedeemonlikkuse sümbolid. Sarnast nivelleerumisfenomeni on täheldanud pisut teises kontekstis ka meediauurija Gertraud Koch, kes on virtuaalkeskkonda Second Life uurides märkinud, et virtuaalruumis oma identiteeti kujundades on inimesel teoreetiliselt (peaaegu) kõik võimalik, ometi selekteeritakse välja teatud üha korduvad teemad ja teisi välditakse. Näiteks ei puudutata Kochi uuritud keskkonnas kunagi selliseid teemasid nagu haigus, vananemine, puuded, viletsus, surm; juhul, kui kujutatakse midagi negatiivset, on see valatud esteetilisse, idealiseeritud vormi (vrd Koch 2009, 227). Selektiivsus algab õigupoolest juba sellest, et vastavasse foorumisse kogunevad ainult teatavate huvidega inimesed - selles mõttes pole tegemist 
kõigile avatud foorumiga, vaid esmane selektsioon toimub juba huvivaldkondade järgi.

Arusaadava tähendusega kasutajanimede hulgas on esoteerikafoorumites üks kõige domineerivamaid nimerühmi mütoloogia/ usundi baasil moodustatud nimed. Sellise taustaga kasutajanimesid (nt Flyghost, Sorts, Igavene Rändur, hing, Muriel, Adriana (viimased kaks inglite nimed), Angelwing, Vaimolend, Lucifer, Meister, rahujumalanna, Sumerite vabastaja) ning usundilise kandvusega esemete ja nähtuste nimetusi (nt Sõrmus, labürint, Kuu) kasutab umbes kolmandik, lisaks olemasolevatest mütoloogilistest ja usundilistest kontseptsioonidest innustatud lähenemised (näiteks mmetalheart, Dark Snake, Dark Wolf, White Wolf) ning kirjanduslikest usunditöötlustest-edasiarendustest ja usundimotiive kasutavatest arvutimängudest inspireeritud (nt Tolkien, Balduran). Mõned kasutajad esinevad sama kasutajanime all ka rohkem kui ühes esoteerikafoorumis. Sellist temaatilist nimevalikut usundit ja esoteerikat puudutavates foorumites on täheldanud ka mõned teiste maade autorid, näiteks märgivad ühte kummituskogemuste üle arutlevat ingliskeelset uudisrühma uurinud folkloristid, et selle liikmete nimed olid kantud enamasti müstitsismi vaimust, sisaldades noppeid rahvausundist, religioonist ja ulmest (Fialkova, Yelenevskaya 2001, 66). Võrdluseks selgub Haya Bechar-Israeli (1996) uurimusest ühe interneti meelelahutusliku vestluskeskkonna kohta, et seal moodustasid kirjandusest, mütoloogiast ja filmidest pärit kasutajanimed ainult $6 \%$ nimede koguhulgast.

Nimevalik on selgelt foorumispetsiifiline ning inimese roll ja rollikäitumine muutub vastavalt keskkonnale, kus ta viibib - pole välistatud, et mõni vägeva mütoloogilise nimega kasutaja esineb perefoorumis tupsununnu ja kohtingusaidis sexykiizu kasutajanime all. Harvematel juhtudel kohtab esoteerikafoorumites siiski ka provotseerivalt naeruväärseid või triviaalseid kasutajanimesid, nagu AnnaNuustik (pesa.ingliabi.ee, para-web.org), SiilFelix, Sardell, säinas (tuulepesa.zzz.ee). Vahel võib aga pealtnäha humoristlik nimi olla ka sügavama tähendusega metafoor, näiteks selgitab AnnaNuustik ise: "Nuustik on tugev, tehtud teraskiududest." Foorumi tuulepesa.zzz.ee saja kõige aktiivsema postitaja hulgas oli humoorikate nimedega kasutajaid alla kümne (nt säinas, rääbis, Jurakas, Jelly-eater).

Kui kasutaja peab vajalikuks oma nime tähendust pikemalt lahti seletada, on uutele liitujatele selleks olemas vastav tervituste ja 
enesetutvustuste rubriik. Näiteks selgitab pesa.ingliabi.ee kasutaja Iris seal oma nime tausta:

Iris (kreeka keeles 'Iors - 'vikerkaar') on vanakreeka mütoloogia järgi isikustatud vikerkaar ja jumalate sõnumitooja. Ta võib olla kas vikerkaare või tiivulise neiu kujul. Nii nagu vikerkaar ühendab taevast ja maad, ühendab Iris jumalaid taevas ja inimesi maa peal. Ta rändab tuulekiirusel ühest maailma otsast teise, samuti mere põhja ja allmaailma. Arvati, et ta vastutab pilvede varustamise eest veega (pesa.ingliabi.ee, dets 2010).

Foorumi para-web.org kasutaja Sekhmet märgib enda nime selgituseks:

Kuid Hathorile (taeva- ja armastuse jumalanna) meeldis tema brutaalne töö nii, et temast tuli SEKHMET-sõja-ja hävingu jumalanna.

Kasutajal on võimalus märkida profiilis ära ka oma asukoht. Asukoha määratlemisel eelistatakse sageli samuti mütoloogilisi või müstilis-mütoloogilise kõlaga kohti: nt Wonderland, Urantia, space, seitsme maa ja mere taga, iidses metsas, unustuste mets, vikerkaarel (tuulepesa.zzz.ee).

Kasutajanimedes ja avatarides väljendub teatav võimu- ja väetaotlus - eelistatakse vägevaid vaimseid tegelasi/sümboleid või ohtlikkust kätkevaid ja ambivalentse karakteriga sümboleid. Üldtendentsina eelistavad naissoost külastajad poeetilisemaid nimesid (nt Iris) ja meesoost külastajad ohtlikumaid (nt Dark Angel) - inimese tegelik sugu selgub foorumivestluse käigus antud vihjetest (nt kui kasutaja viitab endale kui õrnema soo esindajale, emale, pojale). Küberruumi uurija John Suleri sõnul eelistavad vestluskogukondades võimusümboleid sisaldavaid avatare eelkõige noored meeskasutajad (Suler 2007). Mõningatel juhtudel ei ole muidugi võimalik kindlalt aru saada, kas foorumikasutaja on mees või naine. Sel juhul esindabki inimest ainult tema virtuaalne sugu.

Vaid üksikjuhtudel esinevad inimesed oma tegeliku ees- ja perekonnanime all, nt suhtleb Saksa esoteerikafoorumites mitme esoteerikaraamatu autor Matthias Mala, kes on iseenda paigutanud selgesse rolli, tema rõhutatult härrasmehelik käitumine, vanamoodsalt mõjuvad peened ja viisakad pöördumised, ka ründavate pöördumiste peale kõigutamatult rahulik reageerimine loovad allusiooni müstilisele keskaegsele maagile. 


\section{Foorumipostituste laad}

Põhiliselt tuleb esoteerikafoorumite postitustes esile autobiograafiline perspektiiv, vaimumaailmaga kohtumisi esitatakse kui memoraate, millega seoses küsitakse teistelt foorumikasutajatelt seletust või muud abi. Sarnaste kogemuste kirjelduste kuhjumise ning vastavasisuliste raamatute jm allikate tsiteerimine vormib, modelleerib ja modifitseerib samal ajal traditsiooni. Harvemini räägitakse ka "sõbra tuttavaga" juhtunud, juba pikema folkloriseerumisprotsessi läbi teinud lugusid.

Esoteerikafoorumite üks keskseid otseseid funktsioone on sündmuste ja nähtuste tõlgendamine sündmuse kogeja ja/või teiste foorumikasutajate poolt. Tõlgendusmomendi olulisust on traditsioonilise autobiograafilise jutustamise puhul märkinud muuhulgas folklorist Tiiu Jaago: "Küsimusi tõsielu üksikjuhtumeist vahendatakse tõlgenduste kaudu: ei piisa ainult sündmuse läbielamisest (individuaalsest tasandist), vaja on ka tõlgendustasandit (rühmatasand)" (Jaago 2006, 85). Lähtuvalt rühmasiseselt aktsepteeritavatest ja kultuuriliselt etteantud tõlgendusviisidest hakkab üksikisik omakorda tegema valikuid oma kogemuse kirjeldamise ja kasutatavate terminite osas. Näiteks rohelist mehikest näinud foorumikasutaja nimetab teda kõhklematult humanoidiks, inimese ümber tajutavat valguskuma auraks jne. Hoopis harvemini kohtab küsimusi stiilis: nägin rohelist mehikest, kas see oli nüüd surnuvaim või humanoid? Lähtuvalt eelteadmistest on vastavad määratlevad valikud seega juba enne kogemuse verbaliseerimist ära tehtud. Kui ka mõnel foorumikasutajal tekib kahtlusi, millise olendiga ta oma kogemuse ajal võis kokku puutuda, jõutakse foorumiarutelu käigus sobivate järeldusteni, näiteks tuuakse postitustes välja tunnused, mille põhjal ühte või teist olendit (näiteks inglit, poltergeisti) ära tunda või vastupidi - selleks olendiks liigitamine välistada. Rühmareaalsuse loomise protsess on võrreldav nn talupojapärimuse rühmakonteksti mõjuga, millel oli samuti oluline osa pärimuse taasloomisel - ka vanemates muistendites ja pärimusteadetes on üldjuhul üheselt selge, millisest konkreetsest olendist on jutt.

Järgnev on üks klassikaline abipalumisjuhtum foorumist paraweb.org (nov 2010): 
Ma sooviksin saada Teie abi, et leida selgitus oma loole. Kõik algas juba umbes 10 aastat tagasi. Kõik algas nii, et ma ei saanud enam öösiti magada. Ma ärkasin tundega, et keegi lämmatab mind või istub mu peal. Siis hakkasin ka nägema udukogusid, mis aeglaselt ära haihtusid. Ma tundsin, kuidas voodi hakkas mu all värisema ja lausa hüppama. Ja eriti just sealt kohast kus olid mu käed. Ja mu süda peksis nii kõvasti, et ei jõud lugedagi. Siis mul algasid peavalud, mis kestisd pea mitu aastat. Ma ei leidnud kusagil abi ei peavaludele ega oma loole. Siis pöördusin ravitseja poole, kus ma sain oma peavaludest lahti. Ta rääkis ka et mul on mingid liinid lahti ning seega saab iga halva energiaga olematu minuga ühendust ning mu energiat ära võtta. Peale tema juures käiku oli mul algul lihtsam, kadusid ära lämmatamised. [---] Järgneb jutt sellest, kuidas sümptomid uuesti süvenesid.

See võiks samahästi olla ka 19. sajandi või 20. sajandi algupoole traditsiooniline memoraat. Selles esinevad klassikalise painaja sümptomid ja ka abisaamine ravija kaudu (vrd põhjalik käsitlus painajafenomeni kohta Hufford 1989). Ent tänapäeva infoajastul on võrreldes n-ö külaühiskonnaga pärimuslikud interpretatsioonid tunduvalt multikultuursemad ja mitmekesisemad: antud postituse vastustes soovitatakse abiküsijal minna arstile (samas mõned soovitavad kategooriliselt psühhiaatrilistest ravimitest eemale hoida, kuna need võtaksid inimese vaimse tundlikkuse ära), pööratakse asi üldse naljaks, soovitatakse mingit kindlat ravitsejat, kelle kontakt vahendatakse abivajajale; foorumikasutajad üritavad juhtumit ka ise interpreteerida ja pakkuda abivõimalusi lähtuvalt oma kogemuste- ja teadmistepagasist. Muuhulgas diagnoositakse kirjeldatu näiteks šamaanihaigusena ja soovitatakse lugeda folklorist Aado Lintropi "Šamaaniraamatut".

Laiatarbe suhtlusfoorumites peavad inimesed oma seletamatutest või üleloomulikest kogemustest juttu tehes tihti vajalikuks ennetada võimalust, et neid peetakse kergeusklikuks, kinnitades, kuivõrd ratsionaalse või üleloomuliku suhtes skeptilise inimesega on muidu tegemist, näiteks:

Olen 50-aastane, väga ratsionaalse mõtlemisega ega usu kummitusi, ufosid ja muud sellist. Mis puutub kaitseinglisse, siis nimetatagu seda kuidas tahes, oma eluaastate kogemust vaadates ei olegi vaja midagi uskuda, lihtsalt on näha, et valitsevad teatavad seaduspärad erinevate inimeste eludes (naistekas.delfi.ee, 12.02.11). 
Seevastu esoteerikafoorumite kasutajate silmis on vaimse maailma ja paranähtuste olemasolu enamasti väljaspool kahtlust ning rohkete üleloomulikuna interpreteeritavate fenomenide kogemine lisab kasutaja jutule pigem kaalu.

\section{Oma ja võõra opositsioon}

"Oma" ja "võõra" vahekorrad on osalt juba foorumi moderaatorite või liidri poolt paika pandud, osalt aga foorumiliikmete osalusel vabalt kujunevad eelistused.

Üks rühmakuuluvuse väljendamise viise internetifoorumites laiemalt on enda selge eristamine teistest foorumitest ja teistsuguse meelsusega inimestest (tähelepanekuid "oma" ja "võõra" vastanduse väljendumisest laiatarbe internetifoorumites on teinud näiteks Laineste 2012). Juba vaimumaailm.ee avalehe pealkirjas sisaldub vastandumine: "Arengumaagide Foorum. Arengumaagide idee ja elu mõte on vabaneda inglitest ja parasiitidest". Vaimumaailm. ee foorumipostitustes näidatakse ebasoovitavaid või vaenulikuna tajutavaid külastajaid võimalikult pisendatult ja tähtsusetuna, nt nimetades neid putukateks. Skeptik.ee foorumi postituste puhul torkab samuti silma tugev "oma" ja "võõra" eritlus - teisitimõtlejad või siiralt millessegi uskumist väljendavad inimesed on naiivsed, rumalad, mõttetud, naeruväärsed jne. Samasugust vastandumist kohtab Saksa esoteerikafoorumites ja üldfoorumite esoteerikateemade juures, näiteks kinnitab kasutaja Syntronica korduvalt, et foorumikaaslaste väited selgeltnägemise võimalikkuse kohta on "täiesti alusetu jura" ja "lihtsalt piinlikud", selgeltnägijad ise aga olevat "pelgalt teesklejad" (http://forum.frag-mutti.de; jaanuar 2006).

Esineb ka ühtede foorumite demoniseerimist teistes foorumites, näiteks kriitika vaimumaailm.ee kohta foorumis foorum.luuleviilma. ee, kus süüdistatakse teist foorumit inimestega manipuleerimises. Eesti Kristlikus Foorumis (foorum.usk.ee) leitakse, et vaimumaailm. ee tegijad vajaksid otsesõnu deemonite väljaajamist ja psühhiaatrilist ravi (okt 2007). Vastastikku paljastatakse lausa energeetilisi jm vandenõusid, näiteks kasutaja Noble (vaimumaailm.ee; aug 2006) tõstatab küsimuse:

Miks kasutatakse tuulepesas alafoorumite nimede ees kõikenägevat silma ehk illuminaatide üht võimsaimat sümbolit??? Kas tuulepesa veeb on loodudki ehk inimeste eksiteele viimiseks. 
Asjaolu, et silma kujutis on usundilises sümboolikas universaalselt kasutatav, antud kontekstis jutuks ei tule.

Korduvalt väljendatakse otsesõnu oma suhtumist teistesse foorumitesse, näiteks kirjutab vaimumaailm.ee kasutaja Went foorumi tuulepesa.zzz.ee kohta (sept 2004) irooniliselt ja saab kasutaja Tokrodalt samas vaimus vastuse:

Seal on väljavalitud ja natuke "paremad" inimesed.

Tokroda:

Samas on nad piisavalt lollid. Ma oleks neile energiat annud. Aga jah, nad tahtsid mu allutada. Ja jäid mu pakutust ilma.

Samuti märgib Leemo (vaimumaailm.ee, nov 2004) ühele teisele foorumikülastajale vastandudes: "Kohe IQ-st näha, et tuulepesaline."

Kasutaja Hall kass (vaimumaailm.ee, nov 2005) laiendab oma suhtumise kõikidele new age’i huvilistele:

Need New Age siirad jüngrid teevad alailma ühe sita vea - mingit suvalist, isegi kasvõi üsna piiratud tegelast kohates hakkavad tema ümber kurat teab mis imeoreooli punuma.

Reaalelus toimunud kohtumiste kirjeldustes torkab silma samasugune vastandav joon, näiteks kirjeldab üks foorumikasutaja (tuulepesa.zzz.ee, apr 2012) õhustikku esoteerikateemalistel üritustel:

Selgelt on tunda, kuidas seal olev "õhk on paks" igasugu suure egoga para-tädidest, vaimolendite poolt ülevõetud new-agelastest, ringi luusivatest kristlikest usujuppidest ja muudest "karvastest ja sulelistest".

Ka ühe foorumi raames ei hoita hinnangutega kokku, näiteks võidakse teisi foorumikaaslasi vaidlushetkel nimetada "klooniparasiidiks" (vaimumaailm.ee, märts 2008) või püramiidienergia uskumist sildistada "püramidiotismiks" (vaimumaailm.ee, nov 2005; skeptik.ee, mai 2007), seega edastatakse selge sõnum - meie oma kogukonnas usume õigeid asju, aga "teised" valesid. Osalt väljendusvahendite piiratusest tingituna, osalt inforohkuse tõttu esinebki foorumisuhtluses tõenäoliselt tavasuhtlusest sagedamini n-ö mustvalget kategoriseerimist, selget polariseerumist. Nii Eesti kui ka Saksa esoteerikafoorumites olen korduvalt kohanud näiliselt murelikku suhtumist foorumikaaslastesse, mida väljendatakse soovitusega pöörduda oma jutuga otsekohe arsti või psühhiaatri 
poole. Järelduste tegemine, kuivõrd võivad mingeid foorumipostitusi tegelikult mõjutada mõne kasutaja psühhiaatrilised probleemid, ei ole käesoleva artikli eesmärk.

Teiste foorumite puhul on välja toodud meeste ja naiste jagunemist vastandlikeks leerideks (nt Kuldnokk 2002, 56), kuid esoteerikafoorumites selline sooline jaotumine tooniandev ei tundunud.

\section{Hierarhiate kujunemine foorumisiseses suhtluses}

Rühmahierarhia luuakse esoteerikafoorumites mittetavapärasel moel. Hierarhia tipus on eelkõige need, kes ise otsustavad, et tahavad seal olla. Samas on väga lühikese ajaga võimalik saada nn vanaks olijaks, autoriteediks. Ambitsioonikad kasutajanimed on tihti nn virtuaalkarjääri tegemise üks komponente. Nii saab ka tegelikus elus silmapaistmatu inimene asuda foorumis õpetaja ja juhi rolli. Samas puudub vajadus aega ja vaeva nõudvaks hariduse omandamiseks, sest keegi ei küsi tõendusi ei haridustee kohta ega CVd - ammugi ei tee seda abiküsija, kes annab vastutuse oma elumurede lahenemise eest puhtsüdamlikult teadjate kätte.

Terapeudi või teadja rolli võib endale võtta põhimõtteliselt igaüks, sõltumata haridustaustast. Mõned kasutajad võivad küll oma sõnadele veenvuse lisamise huvides viidata, et on õppinud mingit teraapiat, kuid üldjuhul ei selgu, kas tegemist oli mõnetunnise kursusega või ülikooliõpingutega.

Põhirollid foorumis on käesoleva artikli autori hinnangul järgmised:

\section{1. ennast avav abiküsija,}

2. teadja, kes jagab oma teadmisi,

3. teadja, kes hoiab oma teadmised endale,

4. hoiataja,

\section{5. skeptik-kritiseerija.}

Mõningatel juhtudel (küll üsna vähestel) võivad rollid vahetuda ja teadja esineda ka abiküsija positsioonis. Samuti leidub foorumiteemasid, millest vesteldes jäävad samad kasutajad neutraalseks, kuid mõne teise teema puhul käituvad vastavalt allkirjeldatud hierarhiamehhanismidele. Karen Kuldnokk on eristanud Delfi üldfoorumis (delfi.ee) järgmisi diskursuserolle: õpetaja, teadja, kritiseerija ja 
mängija (Kuldnokk 2002), mille puhul võib leida käesolevas artiklis väljatoodutega mõningaid kattuvusi.

Abiküsija rollis esineb kõige sagedamini foorumi noorliige või külaline. Teda vaevab enamasti mingi tema silmis komplitseeritud probleem, millele ta pole suutnud ise lahendust leida, ja pöördub abisaamiseks teiste foorumikasutajate poole. Abiküsija tuleb tihti esoteerikafoorumisse lootusega leida "kiirtee" lahenduseni, vabaneda üleloomulikul, imelaadsel viisil pikka aega kestnud murest. Sellisest soovmõtlemisest ajendatuna on abiotsija aldis eirama vihjeid, mis võiksid kõigutada tema usku abisaamisse. Ta ootaks meelsasti foorumis teadjarollis esinevatelt kasutajatelt üleloomulikke võimeid ja suurt kompetentsust. Ka teadjatele endile meeldib selline kuvand ja nad kalduvad oma erilisi oskusi rõhutama. Nii toimub rollide koostöö. Karen Kuldnokk toob portaali Delfi foorumipostituste põhjal välja teadjaga analoogse rollikategooria - õpetaja -, ja märgib, et õpetajarolliga käib kaasas õpilaseroll, mis toetab õpetaja kõiketeadvat positsiooni (Kuldnokk 2002, 34).

Teadja, kes jagab oma teadmisi. Esoteerikafoorumi poolt ettekirjutatud teadja-kuvandi juurde kuulub pisut üleolev tonaalsus; spontaansus on kontrollitud ja teadjal on peaaegu igale probleemile olemas valmislahendused. Kui teadjal ka mõnikord mingile küsimusele selget vastust ei ole, ei hakka ta oma kõhklusi eksponeerima. Teadja esitab vastuvaidlematu faktina oma oletusi, mis põhinevad sageli samast foorumist või esoteerikaraamatutest saadud infol. Mõningatel juhtudel lisab infole kaalu mõne "guru" tsiteerimine (nt "Luule Viilma on ju ka öelnud", "Osho ütleb oma raamatus, et..."), seega toimub olemasoleva traditsiooni taasloomine oma tõlgenduse lisamise kaudu. Sageli esineb ka seda, kui teadja enesekindlalt väidab, et tal pole vaja mingeid maiseid infoallikaid, kuna talle tuleb kogu info "otse" vaimumaailma esindajatelt. Sisuliselt on tegemist traditsiooni vaba interpreteerimisega siiski olemasolevas raamistuses - lihtsalt tsiteeritava staatus on erinev. Sarnased tähelepanekud on antropoloog Susan Greenwoodil, kes märgib, et maagilises diskursuses sõltub inimese sotsiaalne mõjuvõim suhetest vaimumaailmaga - rohkem on kaalu nende inimeste sõnadel, kelle spirituaalsed kontaktid on n-ö autentsemad (Greenwood 2003: 199). Veenvuse ja autoriteetsuse lisamiseks tuuakse seega välja isiklikud empiirilised kogemused, mis esitatakse sageli vägevama 
ja õigemana kui mõnel eelmisel kommenteerijal. Näiteks kirjutab kasutaja Naine (jaan 2007, vaimumaailm.ee):

Meie, s.t. mina ja ma tean, et ka paljud kaasvõitlejed, teavad, et selleks et näha või korda saata nn "vägitegusid" pole vaja rituaale ja abivahendeid. Sest need on vaid sümboolsed, mis kinnitavad fü̈̈silist tegevust vaimses maailmas ja liturgiliselt annavad väge juurde vaid neile, kellel pole tegelikult usku endasse ja kes tegelikult ei suuda saavutada otse kontakti teispoolsusega ja enda anitireaalsusega!

Eraldi väärib esiletõstmist heatahtliku teadja roll, mille puhul üleolevat hoiakut üldjuhul ei esine.

Teadja, kes hoiab oma teadmised endale. Sellist tüüpi kasutajad vihjavad, et nad teavad palju rohkem, kui välja ütlevad. Näiteks skeptik.ee foorumikasutaja nimega skeptikuskeptik vihjab, et tema teab juba kõike seda, milleni teised alles välja loodavad jõuda, märkides: "Aga pole põhjust ka ette ütelda, pusige edasi :D"

Iroonilis-salapäratsev stiil ja vihjete andmine võimaldavad teadjal jätta endast mulje kui eksperdist, kes teab, kuidas kommunikatsioon vaimumaailmas toimub. Kui abiküsija ei saa millegagi hakkama (nt ei näe aurat, ei suuda needusest vabaneda), siis võib teadja rõhutada, kui lihtsalt see temal välja tuli, stiilis: "kui natuke asjasse süveneda, siis pole mingit probleemi" (vaimumaailm.ee), kuid jätta siiski täpsemad juhtnöörid andmata. Näiteks abiküsija küsimuse peale: "Kas see on võimalik, nt ise endale unenägu luua?", vastab kogenum foorumikasutaja: "Muidugi on see võimalik, aga...", jättes salapäraselt otsad lahti. Üks foorumikasutaja (apr 2004, tuulepesa.zzz.ee) kommenteerib teise kasutaja vastust: "Juhtub sul tihti, et räägid asjadest, millest sul aimu pole?", andes märku, et tema teab, kuidas asjad käivad, aga lihtsalt ei ütle. Vastuste pakkumise asemel halvustavate ja eelkirjutaja positsiooni kõigutavate vastuküsimuste esitamine foorumipostitustes on silma torganud ka teistele uurijatele (vrd nt Kuldnokk 2002, 144). Tihti lisavad esoteerikafoorumite teadjad oma vastustele kaalu, viidates sellistele keerulistele valdkondadele nagu kvantfüüsika, kaoseteooria või fraktaalsed algoritmid.

Hoiataja. Hoiataja rollis esinev teadja annab märku, et ta on veel targem kui eelnimetatud teadjatüübid. Ta kasutab samuti salapärast stiili ja jagab hoiatusi stiilis: kui sa ei ole asjaga piisavalt kursis, siis ei tasu nii keeruliste asjadega mängida. 
Näiteks järgneb vaimumaailm.ee foorumis (juuli 2005) luupainaja vastu abi otsiva kasutaja postitusele dialoog:

\section{Tokroda:Aga proovi sellist môttemudelit, meditatsiooni, et luupainaja ajal hakkad oma energiat tõmbama ülesse, pähe.}

Skyzer: ma ei soovitaks oma energiat pähe tõmmata sest võib juhtuda et koguneb piisavalt palju energiat pähe ja siis on põmm !

Hoiataja võib esineda ka näilise sõbra rollis, märkides, et ta ei tahaks kasutajat sugugi hirmutada, kuid ometi just seda ta oma jutuga teebki.

Skeptik-kritiseerija. Skeptik-kritiseerija teab maailma asju veel paremini kui kõik eelnimetatud. Ta teeb teiste seisukohad maatasa ja toob välja oma (vähemalt iseenda arvates) ratsionaalse selgituse, kusjuures iga kord ei olegi eesmärgiks tõe jaluleseadmine, vaid lihtsalt põhimõtteline opositsiooni jäämine. Saksa folklorist Helmut Fischer nimetab sellist vastanduvat rolli kasutavat isikut - küll pisut teises kontekstis - kontrastfiguuriks (Fischer 2008, 79). Tihti kasutab kritiseeriv postitaja tingivat kõneviisi: ta räägib, kuidas asjad peaksid olema (vrd sarnane tähelepanek Kuldnokk 2002, 40). Nii mõnelgi juhul näib sellise järelejätmatu kritiseerimise puhul rolliga samastumine olevat vähenenud, pigem omandab toimuv mängu iseloomu. Sarnasust mänguga on esile toodud ka mitmete muude sotsiaalsete protsesside kirjeldamisel (vrd nt Geertz 2003, 38jj). Mõned internetiuurijad on postitajate põhjal lausa eraldi rollina välja toonud mängija: foorumikasutaja, kes üritab teistele vastandudes iga hinna eest nalja teha, esitades absurdseid liialdusi ja ettepanekuid (nt Wallace 2002, 96). Esoteerikafoorumites mängija roll siiski nii selgelt ei eristunud, et seda eraldi kategooriana välja tuua.

Kokkuvõtteks võib öelda, et esoteerikafoorumite kommenteerijad apelleerivad küll sageli kõrgemale vaimsusele ja eetilistele normidele kui "tavainimesed" (mis omakorda on osalt teatud määral eneseteadvust tõstev roll), kuid nende väljendusmaneerid on läbilõikelt sarnased muude foorumite omadega. Siiski on üldtonaalsus leebem, näiteks tunduvalt vähem kohtab otsesõnalist ropendamist ja vägivallaähvardusi. Muidugi on ka esoteerikafoorumite endi lõikes märgata agressiivsuse taseme erinevust ning kõikides foorumites esineb paralleelselt ka kirjeldatud hierarhiasüsteemist väljapoole jäävaid kasutajaid. 
Meediauurija Patricia Wallace (2002, 139) märgib, et kahtlemine teise inimese kompetentsuses on internetisuhtluses üldiselt kõige sagedasem agressiooniavaldus. Seda väidet kinnitab ka Eesti materjal, kusjuures üldfoorumites mõnevõrra tugevamalt kui esoteerikafoorumites. Näiteks leiab Karen Kuldnokk Delfi foorumikommentaaride põhjal, et postitustes on põhiline oma eriteadmistele viitamine, õpetuste jagamine ja postituse autori või teiste vestlusosaliste kritiseerimine (Kuldnokk 2002, 14).

\section{Rollide eesmärk}

Analüüsides selgub, et subjektiivne ettekujutus rolliootustest ja nendele vastamine täidab funktsioone, mis on olulised eelkõige kasutaja enda, aga ka kogukonna silmis (ja viimaste täitmise kaudu taas ka üksikisikule endale). Soov argirollidest väljuda võib tuleneda paljudest erinevatest, kohati ka koostoimivatest tõukejõududest nii võimu- ja kontrolliihast, ärihuvidest, eskapistlikest ajenditest kui ka tõsisemast vaimse enesearengu soovist. Järgnev loetelu ei ole kindlasti ammendav, kuid kajastab siiski mõningaid silmatorkavamaid tendentse.

Võim ja kontroll. Interneti vahendusel oma mõtete avalikkusele kättesaadavaks tegemine pakub rollivalikuks ja vastavaks enesepresentatsiooniks peaaegu piiramatuid tasuta võimalusi. Võimalus teiste inimeste hirmusid vähendada (või vahel ka suurendada), seega teisi mõjutades omaenese teadmiste suurust tunnetada, seab teadja rollis olija teatavasse võimupositsiooni. Samastumine vaimu/ usundimaailma vägevatega aitab luua tunde, et inimene suudab valitseda olukordi ja teisi inimesi. Näiteks on vaimumaailm.ee liider Tokroda väitnud, et aastaks 2012 saab temast maailmavalitseja (2013. aasta algupoolel pole seda siiski veel juhtunud) - antikristusele omaste joonte kasutamine enesekirjelduses sisaldab ilmselget võimutaotlust.

Ahvatlev on tõusta esoteerikafoorumis kiirelt eksperdi staatusse ja sellelt positsioonilt sõna võtta. Siin võib tuua paralleeli tähelepanekuga, mis on tehtud raadiosaadete kohta: "Tõeliselt kuumade teemade puhul muutub foorum raadiosaateks, kuhu helistatakse mitte selleks, et mingit seisukohta avaldada, vaid iseenda mõtete kuulamiseks (lugemiseks)" (Shirky 1993, 33; vrd Eesti kontekstis näiteks teatud grupp Vikerraadio saatesse "Vinguviiul" helistajaid). 
Foorumiküsimusele vastamine on küll eelkõige suunatud küsimuse esitajale, kuid erinevalt eravestlusest teavad vastajad, et neil on tegelikult hoopis laiem publik, ja arvestavad sellega oma vestluse sisu sõnastamisel - see peab olema mõistetav mitte ainult küsijale, vaid ka määratlemata hulgale teistele foorumiliikmetele.

Reklaam ja äri. Mitmes foorumis on paralleelselt täheldatav vähem või rohkem varjatud reklaam. Näiteks foorumis pesa.ingliabi. ee vastavad foorumi loojad küsimustele, kuid rõhutavad, et tõelise abi saamiseks palutakse pöörduda ingliabi vahendajate poole, kelle kontaktid ja hinnakiri on sealsamas lehel kirjas (nt inglisõnumite vahendamine või kaugravi seanss á 40 eurot). Nende teenustes pettunud foorumikasutajad elavad oma meelepaha omakorda välja teistes foorumites:

Nad reklaamivad end kui inglipuhastajaid kuid tegelikkuses on salakavalad ja manipuleerijaist saatanad inglinahas.Väidetavalt ravivad ära kõik rasked terviseprobleemid kuid tulemuseks on 40 euri prügikastis ja tervisest võid ainult und näha (para-web.org, kasutaja devilstar, märts 2012).

Või näiteks Matthias Mala lisab Saksa esoteerikafoorumis küsijatele vastates sageli, et tema kirjutatud raamatutes on kõigest pikemalt juttu. Üldiselt võibki võrdlusmaterjalina kasutatud Saksa esoteerikafoorumis märgata rohkem kommertsajenditel tegutsemist, tihti on foorumivastuste juures viide konkreetsele kodulehele, kus saab tutvuda asjakohase hinnakirjaga, ja foorumisse sisenemisel ootab külastajat ees juba rida reklaame stiilis: kaartide panemine ainult 35 eurot, samuti esoteerikateemaline e-pood.

Ka üks Eesti foorumikasutaja toob välja üldisema kommertsialiseerumise tendentsi (03.02.2008, tuulepesa.zzz.ee):

Aga tundub et on jõuliselt tekkimas uued majandusharud, astraalturism, astraalkaubandus (tõsi, tasu tahetakse miskipärast meie rahas) jne, siis tuleb endale aru anda, et vaimsusega ehk teadvuse vabadusega pole sellel mingit pistmist. Pigem lihtsalt vana hea majandusega veidi peenemal tasandil.

Eskapism ja heaolutunne. Esoteerikafoorum on koht, kus teadjad oskavad orienteeruda, teavad mängureegleid ja suudavad seega toimuvat enda huvides kontrollida ja juhtida, olla protsessi kaasloojaks, sest vaimumaailmades on probleemide lahendused alati 
olemas. Oma ideaalmina esiletoomine aitab parandada enesetunnet ja võib mõjuda teraapiliselt. Traditsiooniline ristiusk ei ole paljudele praegusaja inimestele vastuvõetav, seda tajutakse vanamoodsana, jäigana, indiviidi iseseisvust tauniva ja pärssivana (vrd Heelas, Woodhead 2005). Vajadus uskuda millessegi seletamatusse ei ole tänapäeval aga iseenesest kuhugi kadunud, samas soovitakse, et vaimsed asjad toimiksid ühtaegu kiirel, atraktiivsel ja efektiivsel moel.

Teadja annab foorumis küsija hirmudele ja kõhklustele seletuse. Ükskõik, kas see peab paika või mitte, on see siiski seletus ja seega lahenduse väärtusega, kuna aitab fikseerida amorfse hirmu ja ebakindluse. Psühholoogilises mõttes on kirjapandud hirmu iseenesest kergem taluda kui mõttes kantud hirmu, teiste inimeste kaasatus lahenduse leidmisse vähendab üksindust ja aitab üle saada surnud punktist. Sõltumiskalduvusega inimestele võib aga liigne foorumi autoriteetidele allumine mõjuda laastavalt. Abiküsija on valdavalt juhukülaline, seetõttu ei ole ta kursis foorumitraditsiooniga. Vastusevariantide paljususe tõttu võib foorum olla nii ühtede hirmude mahalaadimise kui ka teiste tekkimise koht (vrd Hiiemäe 2008, 249).

Ülevõimendatult võib foorumisuhtlust võrrelda psühhotroopsete ainete kasutamisega - tekib kõikvõimsuse tunne, inimene muutub maailmanabaks, elu käib tema reeglite järgi, ohutunne väheneb. Meediauurija Joan Kristin Bleicher märgib, et seoses interneti pealetungiga asuvad religioossete transtsendentsusekujutelmade asemele virtuaalsed maailmad ja interneti küberruum omandab jumaliku sfääri omadused. Keha (ja ruumi) piiride ületamise kaudu täidab internet inimkonna iidse igatsuse surma ja surmahirmu ületamise järele (vrd Bleicher 2000, 357). Arvutimängudes on inimesel sageli mitu elu või on ta üldse surematu, seega on ta saavutanud võimu elu ja surma üle - samad ideed kajastuvad esoteerikafoorumites. Edastatakse sõnum, et paralleelmaailmad on olulisemad kui igapäevane reaalmaailm ning püütakse näidata reaalset argimaailma imaginaarsena. Näiteks väidab Sorts (05.02.2008, tuulepesa.zzz.ee):

Pigem usuvad nõidusesse täiskasvanud, kes kuulavad ammulisui juttu, et sõnad demokraatia ja vabaturumajandus tekitavad rikkuse ja korra eimillestki lihtsalt niisama, sest tegemist on võlusõnadega.

Asjaolu, kas niisugune maailmakäsitlus inimest toetab või mitte, sõltub konkreetsest isikust. 


\section{Rollikonfliktid ja rollide korrigeerimine}

Rollide loomine on enamasti ühtaegu teadlik ja mitteteadlik. Igal kasutajal on oma tegutsemismotiivid ja ta käitub nii, kuidas loodab kõige tõhusamalt oma eesmärkideni jõuda. Näiteks võib mõne teadja äärmuslikult eneseteadlik esinemine tunduda kõrvaltvaatajatele oma ego upitamisena, kuid teadja ise ei tarvitse tajuda, et jätab teistele riiaka ja upsaka mulje. Samas vajab abiküsija sageli just inimest, kes oleks silmanähtavalt enesekindel - seega kohtuvad nõudmine ja pakkumine.

Üheks tegeliku isiksuse ja foorumis võetud rolli konflikti näiteks on foorumikasutajad (nt Maag), kes kasutavad oma postitustes tänapäeva teismelisele omast slängi ja rohkeid emotikone. Siin põrkuvad kaks rolli - noortele omane cool-olemine vastava netikeele kaudu ning vaimse ja elukogenud inimese roll, millele viitab kasutajanimi.

Vahel toimuvad rollikonfliktid ning teadlik absurdi ja iroonia appivõtmine ka mitme teadjarollis esineja vaidlustes, näiteks:

\section{Tokroda: Jumalad hetkel pü̈̈avad luua uut multiuniversumit}

Kristlane: käisid jälle vaimudega saunas ja kuulsid jah? (vaimumaailm.ee)

Internetifoorumid on teatud mõttes isekorrigeeruvad. Kui inimene muutub liiga originaalseks ja iseteadvaks, pälvib ta kogukonna hukkamõistu, seega tuleb tal kohendada oma käitumist teatud piirides sotsiaalsetele ootustele vastavaks (juhul muidugi, kui ta tahab pikemalt sama nime all foorumis edasi tegutseda). Samas vajab kogukond ka nn peksupoisse ehk ühiseid vaenlasi, ja selles staatuses olev kasutaja võib määratledagi oma identiteeti just mitteaktsepteeritud rolli täitmise kaudu - ka nn märtriidentiteet võib eneseteadvust tõsta, sest see võimaldab inimesel mõelda, et teda ei mõisteta seetõttu, et ta on nii eriline.

Püsivalt agressiivset rollikäitumist - näiteks naeruvääristavat, otsesõnu kaasfoorumlasi mõnitavat kõnepruuki esoteerikafoorumites üldjuhul taunitakse. Samas võivad ka tekkida leerid agressiivsete kasutajate, agressiivsust agressiivselt hukkamõistvate kasutajate ja lepitajate vahel.

Huvitav on asjaolu, et sugugi kõik loodud liikmeprofiilid ei lähe kasutusse, vaid mõne alt tehakse ainult üks-kaks postitust ja seejärel need hüljatakse. On sadu registreeritud kasutajanimesid, 
mille alt pole tehtud ühtegi postitust. Patricia Wallace leiab, et selline nn "pilootidentiteetide" hülgamine toimub eksperimenteerimise eesmärgil: "Internet on identiteetide labor, mis on pungil täis rekvisiite, publikut ja mängijaid, kõik selleks, et läbi viia personaalseid eksperimente" (Wallace 2002, 73). Esoteerikafoorumite põhjal tundub siiski, et teadlikku identiteetidega ridamisi eksperimenteerimist kuigi sageli ei esine, enamasti on eesmärgiks ikka sisuline osalemine.

\section{Lõpetuseks}

Tänapäeva esoteerikafoorumite virtuaalhierarhia tippudele allumine sarnaneb nii mõneski suhtes vanemast talupojakultuurist tuntud nõia, ravija ehk teadja institutsioonile - seda keskkonda kasutatakse nii lahenduste leidmise kui ka vastutuse mahapanemise kohana. Ka vanematest pärimusteadetest võib välja lugeda, et üldjuhul usaldas traditsioonilise rahvaravija juurde pöörduja ravija teadjaautoriteeti kõhklematult. Ent võimalusi teadjana üles astuda on virtuaalmaailmas tunduvalt rohkem ja teadjarolli omandamine on oluliselt lihtsam ja vähem reaalseid tõestusi vajav kui oli traditsioonilises külaühiskonnas. Samas on ka abiotsija valikute spekter märksa laiem. Foorumivestlus rahuldab mõlemale poolele olulisi vajadusi: teadja saab tõsta oma eneseteadvust ja staatust teadja rolli kaudu, abiküsija tunneb kergendust, et saab vastutuse vähemalt näiliselt kellegi teise õlgadele panna ja ebaõnnestumise korral kedagi teist süüdistada. Esoteerikafoorumis abiküsimise ja -andmise atraktiivsuse põhjus on seega osalt sama, mida mõned autorid (nt Puro 1997, 29) on esile toonud alternatiivravi fenomeni puhul: see võimaldab puudutada meie kõige sügavamaid tundeid ja pakkuda lahendusi teaduslikult veel lahendamata probleemidele.

Samas ei taha ma väita, nagu oleks esoteerikahuvi ja esoteerikafoorumites osalemine käsitletav pelgalt "nartsissistliku põgenemisena reaalsusest" (vrd Heelas 2003, 4). Ka ülaltoodud järeldused ei kehti sugugi kõikide kasutaja-ja postitusetüüpide puhul. On teatav hulk pühendunult enda vaimse arendamisega tegelevaid inimesi, kes jäävad ka oma postitustes enamasti tasakaalukaks ja toetavaks ega allu kaaskasutajate provokatsioonidele. Seega pakuvad esoteerikafoorumid kasutajatele väga mitmetahulisi strateegiaid keeruliste olukordadega toimetulemiseks ja maailma mõtestamiseks 
ning ühtlasi võimalust tajuda kontrolli nii mineviku (kontaktid surnute hingedega, mentaalne sünnihetke tagasipöördumine), oleviku (rituaalid, teraapiad) kui ka tuleviku (ennustamine, karma teadlik kujundamine) üle. Foorumikasutajate virtuaalne identiteet ja rollivõtmised foorumis (näiteks teadja ja abiküsija vastastikune täiendamine) toetavad seda mõtestamisprotsessi.

\section{Kirjandus}

Bargh, John A.; McKenna, Katelyn Y. A. 2003. The Internet and Social Life. -Annual Review of Psychology 55, 573-590 (http://dx.doi.org/10.1146/ annurev.psych.55.090902.141922).

Bechar-Israeli, Haya 1996. From <Bonehead $>$ to $<$ cLoNehEAd $>$ : Nicknames, play, and identity on Internet relay chat. - Journal of ComputerMediated communication 1 (http://jcmc.indiana.edu/vol1/issue2/ bechar.html -21. 01.2013).

Bleicher, Joan Kristin 2000. Virtualisierung der Transzendenz. Die Präsentation der Religionen im Internet. - Medien und Erziehung 44 (Heft 6), 356-360.

Delfi Naistekas = http://naistekas.delfi.ee/.

Fialkova, Larissa; Yelenevskaya, Maria N. 2006. Ghosts in the Cyber World. An Analysis of Folklore Sites on the Internet. Fabula 42/1-2, 64-89.

Fischer, Helmut 2008. Sekundengeschichten. Erzählen in Rundfunkwerbesendungen. - Schmitt, Christoph (toim). Erzählkulturen im Medienwandel. Rostocker Beiträge zur Volkskunde und Kulturgeschichte 3. Münster: Waxmann, 75-86.

Geertz, Clifford 2003. Omakandi tarkus. Esseid tôlgendavast antropoloogiast. Tallinn: Varrak. [Originaal: 2000. Local knowledge: further essays in interpretive anthropology. New York: Basic Books.]

Greenwood, Susan 2003. British Paganism, Morality and the Politics of Knowledge. - Caplan, Pat (toim). The Ethics of Anthropology. Debates and Dilemmas. London \& New York: Routledge.

Heelas, Paul 2003. The New Age movement: The celebration of the self and the sacralization of modernity. Cambridge, Massachusetts: Blackwell Publishers.

Heelas, Paul; Woodhead, Linda 2005. The Spiritual Revolution. Why Religion is Giving Way to Spirituality. Religion in the Modern World. Malden, Oxford, Carlton: Blackwell Publishing.

Hiiemäe, Reet 2008. Strategien zur Bewältigung von Ängsten durch massenmediales Erzählen. - Schmitt, Christoph (toim). Erzählkulturen im Medienwandel. Rostocker Beiträge zur Volkskunde und Kulturgeschichte 3. Münster: Waxmann, 245-254. 
Hufford, David 1989. The Terror That Comes in the Night: An ExperienceCentered Study of Supernatural Assault Traditions (Publications of the American Folklore Society). Philadelphia: University of Pennsylvania Press.

Jaago, Tiiu 2006. Individuaalsed valikud ja sotsialiseerumine eluloojutustuste põhjal. - Mäetagused 33. Tartu: EKM rahvausundi ja meedia töörühm, 83-100 (http://www.folklore.ee/tagused/nr33/jaago.pdf $-21.01 .2013)$.

Joinson, Adam N. Understanding the Psychology of Internet Behaviour. Basingstoke \& New York: Palgrave.

Koch, Gertraud 2009. Second Life - ein zweites Leben? Alltag und Alltägliches einer virtuellen Welt. - Zeitschrift für Volkskunde. Halbjahresschrift der Deutschen Gesellschaft für Volkskunde II, 215-232.

Kuldnokk, Karen 2002. Interpersonaalsete suhete kujunemine internetiportaalis comment@delfi. Magistritöö. Tartu: Tartu Ülikool.

Kunz, Arne 2012. Tere tulemast arvutimängu World of Warcraft imelisse maailma. - Hiiemäe, Reet (koost). Mis on ühist Gilgamešil ja geeniuurimisel? Käsitlusi kultuurist ja usundist. Tartu: EKM Teaduskirjastus, Eesti Keele Instituut, 77-99.

Laineste, Liisi 2012. Verbal expressions of aggressiveness in Estonian Internet. - Laineste, Liisi; Brzozowska, Dorota; Chłopicki, Władysław (toim). Estonia and Poland: Creativity and tradition in cultural communication 1. Tartu: ELM Scholarly Press, 205-220 (http://dx.doi. org/10.7592/EP.1.laineste.liisi).

Lintrop, Aado 1995. Šamaaniraamat. Tartu: Ilmamaa.

Puro, Jukka-Pekka 1997. Argumentatsioon, teadus ja näivteadus. - Selin, Risto; Ollikainen, Marketta; Salmi, Ilpo V.; Raig, Kulle (toim). Teine maailm. Kahtleja käsiraamat. Tallinn: K \& K, 26-31.

Reinaus, Reeli 2008. Enesepresentatsioon Perekoolis. - Hiiemäe, Mall; Saarlo, Liina (toim). Tonditosin. Pro folkloristica XIV. Tartu: EKM Teaduskirjastus, 160-181.

Roth, Klaus 2009. Erzählen im Internet. - Erzählkultur: Beiträge zur kulturwissenschaftlichen Erzählforschung. Hans-Jörg Uther zum 65. Geburtstag. Berlin: Walter de Gruyter, 101-120.

Shirky, Clay 1995. Voices from the net. Emeryville, CA: ZD Press.

Suler, John 2007. The Psychology of Avatars and Graphical Space in Multimedia Chat Communities. - The Psychology of Cyberspace (http://users.rider.edu/ suler/psycyber/psyav.html - 21.01.1013).

Wallace, Patricia 2002. Internetipsühholoogia. Rollid elus ja internetis. Tallinn: Valgus. 


\section{Summary}

\section{Roles and Role Behaviour in the Internet Esoteric Forums}

Keywords: internet, esoteric forums, roles, identity, modern folk belief

The article focuses on discussions in asynchronous esoteric forums. The author observes how do forum users create their virtual identity through the choice of user names and profile pictures and to what extent are motives from older folk belief and mythology used in this process. The author also points out characteristics of role behaviour displayed in forum discussions, while exemplifying patterns, functions and purposes of such behaviour. Noteworthy are the manifestation of the opposition 'we' and 'others', the creation of the image of enemy, role conflicts, and the formation of virtual hierachies within single forums as well as between different forums. 


\section{MAAILM ja \\ MULTITASKING}

\section{Koostanud ja toimetanud MARE KÕIVA}

http://www.folklore.ee/rl/pubte/ee/cf/multi

ISBN 978-9949-544-01-1

Tartu 2014

Trükis ilmunud:

MAAILM ja MULTITASKING. Tänapäeva folkloorist 10.

Tartu 2014

Sarja peatoimetaja: Eda Kalmre

Kogumiku koostaja ja toimetaja: Mare Kõiva

Keeletoimetaja: Asta Niinemets

Kaanekujundus: Lilli-Krõõt Repnau

Küljendus: Diana Kahre

HTML: Diana Kahre

Trükist toetasid: teadusteema SF 0030181s08, ETF grant nr 8137 ja IUT22-5 ning Eesti Kultuurkapital.

E-raamatu valmimist toetas: EKKM14-344 Eesti keele, kultuuri ja folkloori kasutusalade laiendamine ja tutvustamine elektroonilistel infokandjatel.
(C) Mare Kõiva
(C) autorid
(C) EKM Teaduskirjastus 2014 